\title{
A lap látogatottsága és legolvasottabb cikkeink
}

\author{
Journal attendance and the most popular articles
}

doi: 10.24365/ef.v59i3.334

Folyóiratunk 2016-os megújulása óta már 10 elektronikus lapszám jelent meg, köztük 2018 áprilisában az első különszámunk, amely a világszerte elismert népegészségügyi szervezetek működését, feladatrendszerét és szolgáltatási portfólióját tekinti át. Az elmúlt időszakban olvasóink száma szinte folyamatosan emelkedett, ezt mutatja be az alábbi ábra. A különszám megjelenésekor a havi látogatószám meghaladta a 8000-et, az elmúlt két hónapban olvasóink átlagos létszáma pedig már több mint napi 200.

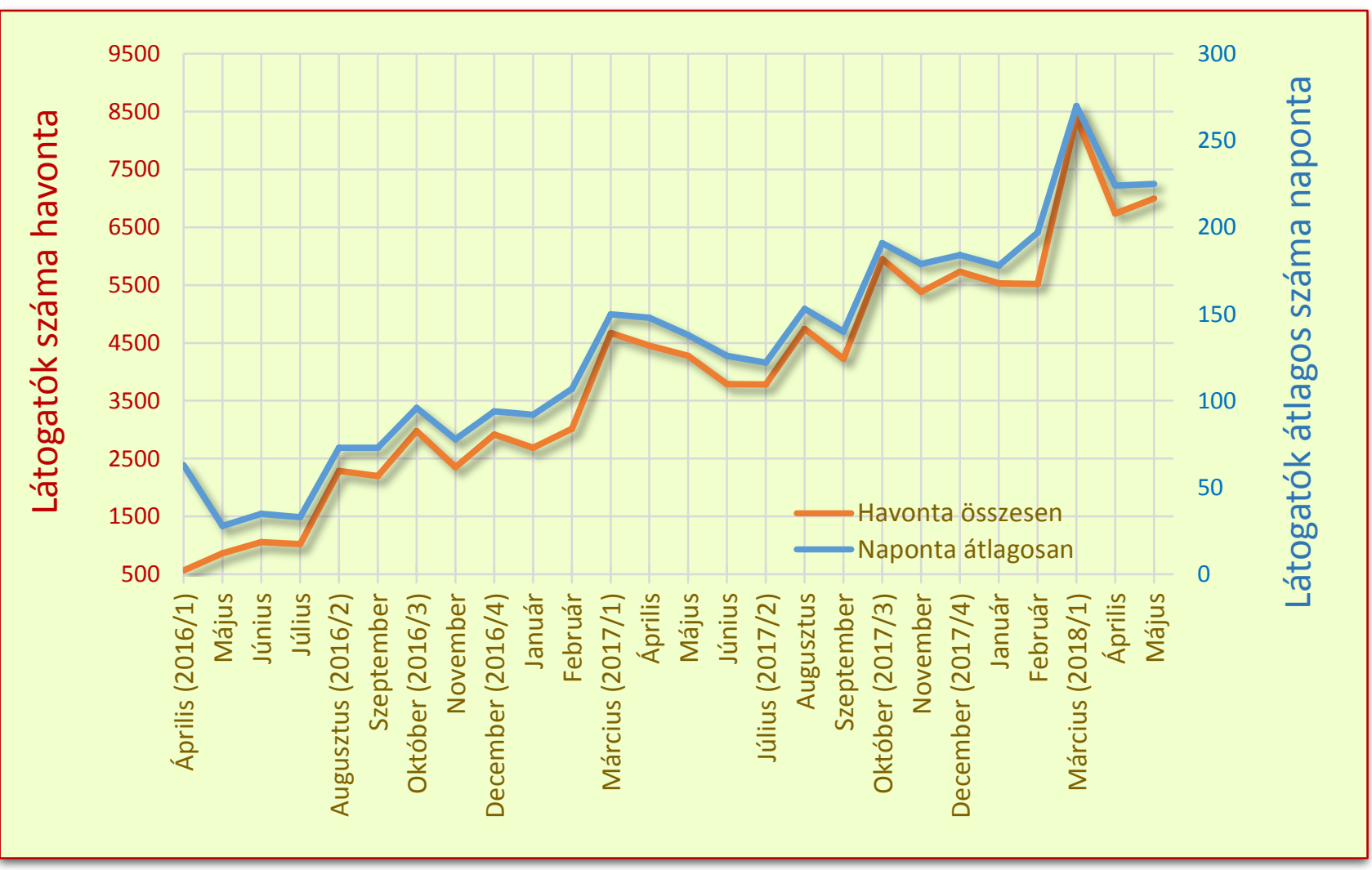

Ismét összeállítottuk a már hagyományos TOP 10es rangsort a leggyakrabban megtekintett összefoglalókról és a legtöbbször letöltött teljes közleményekről. „Érdekességmutatóval” mérjük azt, hogy a megtekintések száma és a megjelenés óta eltelt napok száma hányadosa alapján mennyire bizonyul érdekesnek egy-egy cikk. Ennek alapján a legelőkelőbb helyet a különszám Agora rovatában olvasható közlés foglalja el, amely Magyaror- szág népegészségügyi rendszerét és egészségfejlesztéssel foglalkozó szervezeteit mutatja be. A 10 legérdekesebb cikk között szerepel a szerkesztőség örömére a „Képzelje el!” című sorozatunk első része is, ennek folytatásaként ebben a számban „Akció az irodában” címmel egy egészségfejlesztési iroda munkatársainak egy elképzelt napját mutatjuk be, egy elképzelt világban.... További olvasottsági adatok találhatók az alábbi táblázatban. 


\begin{tabular}{|c|c|c|c|}
\hline \multicolumn{2}{|c|}{$\begin{array}{l}\text { Megtekin- } \\
\text { tések száma }\end{array}$} & \multicolumn{2}{|r|}{ Lapszám } \\
\hline \multicolumn{2}{|c|}{ ÖSSZEFOGLALÓ } & & \\
\hline 713 & Pályázati felhívás tudományos közlemény írására mesterképzéses hallgatóknak & szerkesztőség & 2018/1 \\
\hline 572 & Egészséges életmóddal kapcsolatos kutatások a hazai iskolákban & Járomi É, Szilágyi K, Vitrai J & $2016 / 1$ \\
\hline 466 & $\begin{array}{l}\text { A 2015/2016. tanév országos fittségmérési eredményei a Nemzeti Egységes } \\
\text { Tanulói Fittségi Teszt (NETFIT®) alapján }\end{array}$ & Csányi T, Kaj M & $2017 / 4$ \\
\hline 451 & A kortársbántalmazás (bullying) mint népegészségügyi probléma & Várnai D, Zsíros E, Németh Á & $2016 / 4$ \\
\hline 404 & $\begin{array}{l}\text { A gyógytestnevelés jelentősége a szekunder rehabilitáció és egészségfejlesztés } \\
\text { folyamatában, megújulásának szükségessége, irányai }\end{array}$ & Simon I, Kajtár G & 2018/1 \\
\hline 394 & $\begin{array}{l}\text { Egészpályás letámadás a kövérség ellen - Komplex beavatkozásokkal az elhízás } \\
\text { visszaszorítására }\end{array}$ & Vitrai J, Bakacs M & $2017 / 4$ \\
\hline 372 & Hazai egészség-pillanatkép, 2017 & Vitrai J, Bakacs M, Varsányi P & $2017 / 4$ \\
\hline 352 & Új hazai egészségmonitorozási koncepció & Varsányi P et al. & $2016 / 1$ \\
\hline 336 & A magyarországi egészségértés nemzetközi összehasonlításban & Koltai J, Kun E & $2016 / 3$ \\
\hline 335 & Miért van szükségünk közösségalapú egészségfejlesztésre? & Benyó B & $2017 / 4$ \\
\hline \multicolumn{2}{|c|}{ TEUES KÖZLEMÉNY } & & \\
\hline 2643 & A csecsemőkori allergia-megelőzés korszerú irányelvei és lehetőségei & Réthy A & $2017 / 1$ \\
\hline 745 & Egészségfejlesztési Irodák hálózata & Bezzegh P & $2016 / 1$ \\
\hline 679 & Egészséges életmóddal kapcsolatos kutatások a hazai iskolákban & Járomi É, Szilágyi K, Vitrai J & $2016 / 1$ \\
\hline 423 & OKOSTÁNYÉR ${ }^{\circledast}$ - új táplálkozási ajánlás a hazai felnőtt lakosság számára & Szűcs Zs & $2016 / 4$ \\
\hline 318 & Az iskolai egészségfejlesztés hazai és nemzetközi szemléletének bemutatatása & Járomi É, Vitrai J & $2017 / 1$ \\
\hline 294 & Hazai egészség-pillanatkép, 2017 & Vitrai J, Bakacs M, Varsányi P & $2017 / 4$ \\
\hline 244 & $\begin{array}{l}\text { Összefoglaló „A munkahelyi egészségfejlesztés általános szervezeti megvalósí- } \\
\text { tására vonatkozó szakmai útmutató”-ról }\end{array}$ & Solymossy J, Koós T & $2016 / 3$ \\
\hline 229 & A korai iskolaelhagyás csökkentését célzó szakpolitika - ismertető & Solymossy J & $2016 / 4$ \\
\hline 228 & Amerikai Táplálkozási Ajánlás 2015-2020 - rövid ismertetés & Fekete $\mathrm{K}$, Henter I & $2016 / 2$ \\
\hline 217 & $\begin{array}{l}\text { 2016-os Éves Jelentés a kábítószerhelyzetröl - rövid összefoglaló [2016 Natio- } \\
\text { nal Report on the state of the drugs problem - short summary] }\end{array}$ & Fekete $\mathrm{K}$, Henter I & $2016 / 4$ \\
\hline \multicolumn{2}{|c|}{ "ÉRDEKESSÉG" } & & \\
\hline 6,02 & $\begin{array}{l}\text { Magyarország népegészségügyi rendszere és egészségfejlesztéssel foglalkozó } \\
\text { szervezetei }\end{array}$ & Túri G et al. & $\begin{array}{l}\text { 2018/1 } \\
\text { különszám }\end{array}$ \\
\hline 6,00 & A csecsemőkori allergia-megelőzés korszerú irányelvei és lehetőségei & Réthy A & $2017 / 1$ \\
\hline 3,59 & $\begin{array}{l}\text { A mintaadó népegészségügyi rendszerek elemzéséből levonható tanulságok és } \\
\text { következtetések }\end{array}$ & Túri G et al. & $\begin{array}{l}2018 / 1 \\
\text { különszám }\end{array}$ \\
\hline 2,57 & $\begin{array}{l}\text { Anglia népegészségügyi rendszere és egészségfejlesztéssel foglalkozó szerveze- } \\
\text { tei }\end{array}$ & Túri G, Szőke K & $\begin{array}{l}\text { 2018/1 } \\
\text { különszám }\end{array}$ \\
\hline 2,05 & Pályázati felhívás tudományos közlemény írására mesterképzéses hallgatóknak & szerkesztőség & 2018/1 \\
\hline 1,93 & $\begin{array}{l}\text { Kortárs egészségfejlesztési programok gyermekek és fiatalok körében a hazai és } \\
\text { a nemzetközi szakirodalom tükrében - Szisztematikus áttekintés }\end{array}$ & Lukács-Jakab Á et al. & 2018/1 \\
\hline 1,71 & Hazai egészség-pillanatkép, 2017 & Vitrai J, Bakacs M, Varsányi P & $2017 / 4$ \\
\hline 1,47 & $\begin{array}{l}\text { A gyógytestnevelés jelentősége a szekunder rehabilitáció és egészségfejlesztés } \\
\text { folyamatában, megújulásának szükségessége, irányai }\end{array}$ & Simon I, Kajtár G & 2018/1 \\
\hline 1,27 & Hogyan kellene az egészségkultúrát megváltoztatni? - cikkismertetés & Vitrai J & 2018/1 \\
\hline 1,19 & Képzelje el! & szerkesztőség & 2018/1 \\
\hline
\end{tabular}

